\title{
Improving the quality of reproduction and quail production (Coturnix coturnix japonica) with liquid probiotics
}

\author{
Emmy Susanti and Elly Tugiyanti*
}

\author{
Faculty of Animal Science, University of Jenderal Soedirman, Purwokerto, Indonesia \\ *Corresponding author email: tugiyanti.elly@gmail.com
}

\begin{abstract}
This study aimed to determine the effect of various liquid probiotics in drinking water on the quality of quails' reproductive tract and production. The study used a Completely Randomized Design with four treatments, i.e., drinking water without liquid probiotics (P0), drinking water + commercial probiotics $A(P 1)$, drinking water + commercial probiotics B (P2), and drinking water + commercial probiotics C (P3). The treatment was repeated 5 times and each unit contained 5 quails. Drinking water was given ad libitum with liquid probiotic concentration of $2 \mathrm{ml} /$ litre. Quail feed contains $22.2 \%$ crude protein and $3032.5 \mathrm{kcal} / \mathrm{kg}$ metabolic energy. The observed variable were the weight and length of reproductive tract, egg weight, final body weight, slaughtered weight, dressed carcass weight, heart weight, gastrointestinal weight and lenght of caeca. Quail drinking water consumption was $2.48-2.74$ times the consumption of feed. Analysis of variance showed that the liquid probiotic significantly affected the weight and length of the reproductive tract, egg weight, weight before and after slaughtered, weight after hair removal, heart weight, and gastrointestinal weight. There was no significant effect on carcass weight, liver weight, follicular weight, gizard weight, digestive tract length and caeca length. In conclusion, liquid probiotics in drinking water produced different final body weight, digestive tracts and the size of reproduction tracts of quails than those in control group. The supplementation also increased the weight and length of quails' reproductive tracts. Compared to other probiotics, liquid probiotics A in drinking water produced the highest final weight, post-slaughter weight, dressed carcass weight, liver weight and digestive tracts weight.
\end{abstract}

Keywords: probiotics, quail, reproduction, production

Abstrak. Penelitian ini bertujuan untuk mengetahui pengaruh penggunaan berbagai probiotik berbentuk cair dalam air minum terhadap kualitas saluran reproduksi dan produksi puyuh. Penelitian menggunakan Rancangan Acak Lengkap pola searah dengan empat perlakuan yaitu: puyuh mendapat air minum tanpa probiotik cair $\left(P_{0}\right)$, puyuh mendapat air minum dengan probiotik komersil $A\left(P_{1}\right)$, puyuh mendapat air minum dengan probiotik komersil $B\left(P_{2}\right)$, dan puyuh mendapat air minum dengan probiotik komersil $C\left(P_{3}\right)$, ulangan 5 kali dan 5 ekor puyuh pada setiap unit penelitian. Air minum diberikan secara ad libitum dengan konsentrasi probiotik cair $2 \mathrm{ml} /$ liter. Pakan puyuh mengandung PK 22,2\% dan energi 3032,5 kkal. Peubah yang diamati adalah bobot saluran reproduksi, bobot telur dan panjang saluran reproduksi, bobot potong, bobot setelah disembelih, bobot dress carcass, bobot jantung, berat saluran cerna, bobot karkas, bobot hati, bobot folikel, bobot gizard, panjang saluran pencernaan dan panjang caeca. Konsumsi air minum puyuh 2.48 - 2.74 kalinya konsumsi pakan. Hasil analisis variansi menunjukkan bahwa penambahan probiotik cair ke dalam air minum berpengaruh sangat nyata terhadap bobot saluran reprodukasi, bobot telur dan panjang saluran reproduksi, bobot potong, bobot setelah disembelih, bobot dress carcass, bobot jantung, berat saluran cerna, tetapi berpengaruh tidak nyata terhadap bobot karkas, bobot hati, bobot folikel, bobot gizard, panjang saluran pencernaan dan panjang caeca. Kesimpulan dari penelitian ini bahwa penambahan probiotik cair ke dalam air minum berbeda dengan kontrol terhadap bobot akhir, saluran pencernaan dan saluran reproduksi puyuh. Penambahan probiotik cair ke dalam air minum puyuh meningkatkan bobot dan panjang saluran reproduksi. Penambahan probiotik cair A ke dalam air minum puyuh menghasilkan bobot akhir, bobot puyuh setelah dikeluarkan darahnya, bobot dressed carcass, bobot hati dan bobot saluran pencernaan paling tinggi dibandingkan probiotik yang lain.

Kata kunci: probiotik, puyuh, reproduksi, produksi

\section{INTRODUCTION}

Quail is a type of poultry that gains popularity as a producer of eggs and meat. Quail productivity was reflected from its population in 2013 of $4,741,170$ heads with a growth rate of $3.75 \%$ and egg production of $7,059,767 \mathrm{~kg}$ with $2.60 \%$ of which were hatched (Department of Animal Husbandry and Animal 
Health of Central Java Province, 2014). Quail livestock development requires quality feed support for maximum productivity. Quality feed must contain nutrients for age development and breeding goals (Resnawati and Bintang, 2014). Supplementing probiotics into quality feed is considered safer for livestock products and beneficial for maintaining the health of the host, thus affecting reproductive performance and production. Probiotics are defined as single cultures or live microbial mixtures which, when applied in adequate doses, would benefit the host by maintaining healthy digestive tract (Antoine, 2010). Commercial probiotics are available in solid and liquid forms from various brands with different microbial compositions and sometimes supplements. This research aims to shed lights on improving the quality of digestive and reproduction tracts of quails
(Coturnix coturnix japonica) with commercial liquid probiotics through drinking water.

\section{MATERIALS AND METHODS}

\section{Materials}

The study was conducted at Ketapang Farm and the Laboratory of Nutrition Science and Animal Feed at the Faculty of Animal Husbandry, Universitas Jenderal Soedirman. The research was conducted from 1 September to 19 November 2018. The equipment included 20 experimental cages, cage curtains, scales (0.1g sensitivity), measuring devices $(1 \mathrm{~mm}$ sensitivity), measuring cups $(0.1 \mathrm{ml}$ sensitivity), knives and trays. The research materials were one hundred 30-day-old female laying quails, commercial probiotics A, B and C (Table 1), and quail feed for production period with $22.20 \%$ Crude Protein (CP) and $3032.5 \mathrm{kcal}$ GE (Table 2).

Table 1. Microbial composition and other components of liquid treatment probiotics

\begin{tabular}{cll}
\hline \multicolumn{1}{c}{ Probiotic } & Microorganism & Other components \\
\hline Probiotic A & Lactobacillus $s p$, & Curcuma extract \\
& Rhodopseudomonas, & Nutrients (Protein, Ca, \\
& Streptococcus, & Mg, P and Vitamine C) \\
& Saccharomyces, & \\
\hline Probiotic B & Acetobacter paspalii, & Curcuma extract \\
& Bacillus sp, & Mahkota Dewa extract \\
& Pseudomonas fluorescens, & \\
& Sarcinalutea, & \\
& Lactobacillus sp, & \\
& Staphylococcus epidermis, & \\
& Streptococcus thermophyllus, & \\
& Saccharomyces cerevisiae & Molases $50 \mathrm{ml}$ \\
& Pichia anomala. & Water \\
\hline Probiotic C (EM4) & Lactobacillus casei1, $5 \times 10^{6} \mathrm{cfu} / \mathrm{ml}$ & \\
& Saccharomyces cerevisiae $1,5 \times 10^{6} \mathrm{cfu} / \mathrm{ml}$ \\
& Rhodopseudomonas palustris $1,0 \times 10^{6} \mathrm{cfu} / \mathrm{ml}$ & \\
\hline
\end{tabular}

Table 2. Chemical composition of quail ration

\begin{tabular}{lccccc}
\hline Feeds & Level(\%) & $\mathrm{CP}(\%)$ & $\mathrm{GE}(\mathrm{kkal})$ & $\mathrm{Ca}(\%)$ & $\mathrm{P}(\%)$ \\
\hline Corn & 42.5 & 3.8 & 1402.5 & 0.0085 & 0.1147 \\
Rice bran & 25.0 & 2.9 & 625.0 & 0.0350 & 0.1500 \\
SBM & 20.0 & 10.0 & 565.0 & 0.0540 & 0.1360 \\
Ish meal & 10.0 & 5.5 & 264.0 & 0.3800 & 0.2800 \\
Top Mix & 0.50 & - & 0.0 & 0.0269 & 0.0027 \\
Corn oil & 2.0 & - & 176.0 & 0.0 & 0.0 \\
\hline Sum & 100.0 & 22.2 & 3032.5 & 0.5044 & 0.6880 \\
\hline
\end{tabular}

Analysis by Laboratory of INMT Faculty of Animal Science, Universitas Jenderal Soedirman, Purwokerto 


\section{Method}

The study used a Completely Randomized Design (CRD) with 4 treatments and 5 replications. The treatments were probiotics supplement in drinking water, namely $\mathrm{PO}=$ without probiotics, $\mathrm{P} 1=$ probiotics $\mathrm{A}, \mathrm{P} 2=$ probiotics $\mathrm{B}$, and $\mathrm{P} 3=$ probiotics $\mathrm{C}$. Each treatment unit consisted of 5 quails, and parameters that showed significant difference were subjected to HSD test. Quails were fed twice a day with $20 \mathrm{~g}$ feed (per head/day) containing $22.2 \% \mathrm{CP}$ and $3032.5 \mathrm{kcal}$ energy. The variables observed were the weight and length of the reproductive tract, follicle weight, pre-slaughter weight post-slaughter weight, weight without feathers, carcass weight, heart weight, heart weight, gizzard weight, digestive tract weight, digestive tract length and caeca length.

\section{RESULTS AND DISCUSSION}

\section{Drinking Water and Feed Consumption of Quails}

The effect of liquid probiotics on quail drinking water consumption is presented in Table 3. Daily drinking water consumption for quails in this study was relatively similar to that of Sudrajat et al. (2015), Rinawidiastuti et al. (2019) and Widyastuti et al. (2014) namely $172.67 \pm 14.14 \mathrm{ml}-248.42 \pm 63.08 \mathrm{ml}$ per four quails, 59,69-68,23 ml/day/quail, and 44.31 $\mathrm{ml} / \mathrm{head} /$ day quail, respectively. Despite the different types of probiotics in this study, quails average daily water intake was relatively similar (50.51 $\mathrm{ml} / \mathrm{head} /$ day) which is approximately twice as much as the feed intake. Statistical tests showed that the effect of liquid probiotics was not significantly different $(P>0.05)$ on drinking water consumption because the microbial effectiveness of each probiotic on quail feed consumption was relatively the same. Quails generally eat two to three times a day. Quail's feed consumption in this research (P0) was $18.87 \pm 1.92-20.02 \pm 1.56 \mathrm{~g} / \mathrm{head} /$ day, while the water intake was 2.48 to 2.74 times of feed consumption. Quail drinking water consumption in this study was slightly higher than 2 times in poultry at growth period (Risnajati, 2011) and 2 to 2.3 times (Altine et al. 2016), but lower than 3 times in a study by Marsudi (2012).

The analysis of variance showed that the addition of liquid probiotics had no significant effect $(P>0.05)$ on feed consumption, partly due to the effectiveness of microbes in probiotics as well as the same dose of probiotics added to drinking water. As a result, the effect on intestinal physiology was also relatively similar. It was in accordance with Prawitya et al. (2014) that probiotics can perform their functions according to the microbial specifications if the environment is suitable; therefore, it maximizes the digestion and feed digestibility process.

Table 3. Drinking water and feed consumption of quails supplemented with liquid probiotics ( $\mathrm{ml} / \mathrm{head} /$ day)

\begin{tabular}{ccc}
\hline Treatments & $\begin{array}{c}\text { Average of drinking water consumption } \\
(\mathrm{ml} / \text { head/day) }\end{array}$ & $\begin{array}{c}\text { Average of feed consumption } \\
\text { (g/head/day) }\end{array}$ \\
\hline $\mathrm{P}_{0}$ & $49.03 \pm 7.44$ & $19.77 \pm 0.59$ \\
$\mathrm{P}_{1}$ & $51.83 \pm 7.23$ & $18.87 \pm 1.92$ \\
$\mathrm{P}_{2}$ & $50.68 \pm 5.00$ & $20.02 \pm 1.56$ \\
$\mathrm{P}_{3}$ & $48.66 \pm 4.44$ & $19.52 \pm 0.89$ \\
Average & $50.51 \pm 6.02$ & $19.77 \pm 0.59$ \\
\hline
\end{tabular}

$P_{0}=$ drinking water without probiotic, $P_{1}=$ drinking water + probiotic $A, P_{2}=$ drinking water + probiotic $B$ dan $P_{3}=$ drinking water + probiotic $\mathrm{C}$ 


\section{Reproductive Tracts of Quail}

The effect of liquid probiotics on the quail reproductive tract is presented in Table 4 . The research reported quail reproductive tracts weight (18.91-21.21g), follicular weights (3.98$4.59 \mathrm{~g}$ ) and quail reproductive tract length (21.70-25.38 mm). These results are similar to those of Hilkias et al. (2015), i.e. 6,127-6,674g, 3,238-4,166 g and 22,91-26,57mm, respectively.

Analysis of variance showed that liquid probiotics in drinking water had a significant effect $(P<0.05)$ on weight and length of reproductive tract because the probiotics increase the digestibility of nutrients, including protein. Protein in the body can increase oviduct development and follicular development (Hilkias et al., 2017). The use of probiotics $C$ clearly resulted in the highest weight of reproductive tract. Probiotic bacteria work by sticking to the intestinal mucosa to form a layer that prevents pathogenic bacteria from developing, thereby increasing the work of the digestive tract and intestinal health as well as improving intestinal microflora (Mountzouris et al., 2010). The ideal digestive tract

environment made optimal absorption of nutrients by the small intestine villi. Hidayat et al., (2016) reported a marked increase in intestinal villi length, intestinal villi width and depth of intestinal crypts in male quails that orally supplemented with probiotics containing BAL 107-9 CFU / ml/head/day. Optimal nutrient absorption enables an adequate nutrient to support the growth and optimal performance of the reproductive tract as indicated by the weight of eggs and the length and weight of reproductive tract. Reproductive ability is related to the adequacy of feed energy status (Estrada-Cortés et al., 2009).

\section{Productivity and Digestive Tracts of Quail}

The effect of suplementation of liquid probiotics in quail drinking water on the quality of quail production is presented in Table 5 . The final body weight of quail (quail pre-slaughter weight) in this study was relatively higher than the previous studies, i.e. $131.20 \pm 2.94-139.40$ \pm 4.764 g (Tugiyanti et al. 2018). However, the quality of other carcass characteristics were higher than those reported by Sarjana et al. (2010).

Table 4. Effect liquid probiotics on reproductive tracts of male quails

\begin{tabular}{cccc}
\hline Treatments & $\begin{array}{c}\text { Weight of the } \\
\text { reproductive tract }(\mathrm{g})\end{array}$ & $\begin{array}{c}\text { Follicular weight } \\
(\mathrm{g})\end{array}$ & $\begin{array}{c}\text { Length of reproductive } \\
\text { tract }(\mathrm{mm})\end{array}$ \\
\hline $\mathrm{P}_{0}$ & $18.91 \pm 1.70^{\mathrm{a}}$ & $3.98 \pm 1.93$ & $21.90 \pm 2.08^{\mathrm{a}}$ \\
$\mathrm{P}_{1}$ & $20.41 \pm 1.88^{\mathrm{bc}}$ & $4.59 \pm 1.04$ & $23.91 \pm 1.45^{\mathrm{b}}$ \\
$\mathrm{P}_{2}$ & $20.23 \pm 1.37^{\mathrm{b}}$ & $4.49 \pm 1.48$ & $21.70 \pm 1.37^{\mathrm{a}}$ \\
$\mathrm{P}_{3}$ & $21.21 \pm 1.64^{\mathrm{c}}$ & $4.49 \pm 0.08$ & $25.38 \pm 0,56^{\mathrm{c}}$ \\
\hline Average & $19.99 \pm 1.48$ & $4.39 \pm 1.52$ & $23.22 \pm 1.69$ \\
\hline
\end{tabular}

$P_{0}=$ drinking water without probiotic, $P_{1}=$ drinking water with probiotic $A, P_{2}=$ drinking water with probiotic $B$ dan $P_{3}=$ drinking water with probiotic $C$, abc Different superscripts within column indicate significant difference $(P<0.05)$

Table 5. Quality of quail production receiving liquid probiotics through water drink

\begin{tabular}{ccccc}
\hline Treatments & $\begin{array}{c}\text { Final body } \\
\text { weight }(\mathrm{g})\end{array}$ & $\begin{array}{c}\text { Post-slaughter } \\
\text { weight }(\mathrm{g})\end{array}$ & $\begin{array}{c}\text { Weight of dress } \\
\text { carcass }(\mathrm{g})\end{array}$ & $\begin{array}{c}\text { Weight of } \\
\text { carcass }(\mathrm{g})\end{array}$ \\
\hline $\mathrm{P}_{0}$ & $159.12 \pm 3.12^{\mathrm{b}}$ & $152.27 \pm 3.44^{\mathrm{b}}$ & $141.78 \pm 4.90^{\mathrm{b}}$ & $88.30 \pm 4.86$ \\
$\mathrm{P}_{1}$ & $163.14 \pm 1.45^{\mathrm{c}}$ & $155.56 \pm 3.91^{\mathrm{c}}$ & $148.54 \pm 5.81^{\mathrm{c}}$ & $88.20 \pm 5.42$ \\
$\mathrm{P}_{2}$ & $148.66 \pm 1.86^{\mathrm{a}}$ & $143.80 \pm 3.86^{\mathrm{a}}$ & $138.58 \pm 6.92^{\mathrm{a}}$ & $88.98 \pm 6.27$ \\
$\mathrm{P}_{3}$ & $156.24 \pm 2.55^{\mathrm{b}}$ & $152.18 \pm 4.48^{\mathrm{b}}$ & $143.14 \pm 5.88^{\mathrm{b}}$ & $88.21 \pm 3.99$ \\
\hline Average & $156,79 \pm 2.76$ & $150.95 \pm 3.92$ & $143.01 \pm 5.64$ & $88.42 \pm 5.43$ \\
\hline
\end{tabular}

$\mathrm{P}_{0}=$ drinking water without probiotic, $\mathrm{P}_{1}=$ drinking water with probiotic $A, P_{2}=$ drinking water with probiotic $B$ dan $P_{3}=$ drinking water with probiotic $C$, abc Different superscripts within column indicate a highly significant difference $(P<0.01)$ 
Probiotics B resulted in the lowest quail final body weight, post-slaughter weight and dressed carcass weight. Analysis of variance showed that the suplementation of liquid probiotic had a highly significant effect $(P<0.01)$ on final body weight and quail post-slaughter weight, dress carcass weight and carcass weight. HSD test showed that the final body weight at $P_{2}$ is different from $P_{0}, P_{1}, P_{3}$, also between $P_{1}$ and $P_{3}$; the post-slaughter weight at $P_{2}$ was different from $P_{0}, P_{1}, P_{3}$ and the dress carcass weight at $P_{1}$ was different from $P_{0}, P_{2}, P_{3}(P<0.05)$. $P 2$ treatment on the three parameters of final body weight showed the lowest results across treatments although the microbes in P2 were more varied than those in $\mathrm{P} 1$ and $\mathrm{P} 3$. There was a suspected competition between microbes in utilizing feed nutrients which hindered the microbes' role in protecting the intestinal environment. Similar case was reported where the formation rate of acetic acid added with $15 \%(\mathrm{v} / \mathrm{v})$ Acetobacter xylinum inoculum was lower than that of $10 \% \mathrm{v} / \mathrm{v}$ because the microorganisms were competing to use the existing nutrients or substrates (Aditiwati and Kusnadi, 2003).

The analysis of variance result showed that liquid probiotic supplementation in drinking water had no significant effect $(P>0.05)$ on the weight of the liver and gizzard as well as the length of digestive tracts and caeca. However, it showed a very significant effect $(P<0.01)$ on heart weight and a significant effect $(P<0.05)$ on the weight of digestive tracts. The weight of heart and quail digestive tracts after being given probiotics increased because the probiotic supplementation increased digestion and metabolic processes. Body metabolism processes will increase the heart work to help circulate the oxygen through the blood. This is in accordance with Pittman and Rafael (2011) and Kubale et al. (2018) that the interplay of respiration, circulation, and metabolism is the key to the functioning of the respiratory system as a whole. The systemic circulation and pulmonary circulation are connected in series through the four chambers of the heart so that all blood pumped from the left ventricle into the systemic organs eventually makes its way back to the right ventricle from where it is pumped into the lungs. The main purpose of respiration is to provide oxygen to the cells at a rate adequate to satisfy their metabolic needs.

The heart weight of P2 was the lowest because the variation of microbes in $\mathrm{P} 1$ and $\mathrm{P} 3$ the is less than that in P2. An optimal population can be achieved if a dose of probiotics is added to drinking water, i.e. $2 \mathrm{ml} / \mathrm{L}$ drinking water. Probiotics can improve the digestive tract and increase the digestibility of feed by suppressing pathogenic bacteria in the digestive tract in order to support the development of beneficial bacteria that help the absorption of food substances (Kompiang, 2002).

Table 6. Weight and length of digestive organs and tracts of quail

\begin{tabular}{ccccccc}
\hline Treatments & $\begin{array}{c}\text { Weight of } \\
\text { liver }(\mathrm{g})\end{array}$ & $\begin{array}{c}\text { Weight of } \\
\text { heart }(\mathrm{g})^{* *}\end{array}$ & $\begin{array}{c}\text { Weight of } \\
\text { gizzard }(\mathrm{g})\end{array}$ & $\begin{array}{c}\text { Weight of } \\
\text { digestive } \\
\text { tract }(\mathrm{g})^{*}\end{array}$ & $\begin{array}{c}\text { Leght of } \\
\text { digestive } \\
\text { tract }(\mathrm{mm})\end{array}$ & $\begin{array}{c}\text { Leght of } \\
\text { Caeca } \\
(\mathrm{mm})\end{array}$ \\
\hline $\mathrm{P}_{0}$ & $4.00 \pm 0.19$ & $1.02 \pm 0.01^{\mathrm{a}}$ & $3.69 \pm 0.61$ & $12.79 \pm 2.98^{\mathrm{a}}$ & $68.00 \pm 4.79$ & $8.66 \pm 1.33$ \\
$\mathrm{P}_{1}$ & $3.94 \pm 0.07$ & $1.83 \pm 0.01^{\mathrm{c}}$ & $4.03 \pm 0.21$ & $14.77 \pm 4.43^{\mathrm{c}}$ & $68.74 \pm 5.94$ & $8.74 \pm 2.05$ \\
$\mathrm{P}_{2}$ & $3.87 \pm 0.04$ & $1.33 \pm 0.03^{\mathrm{b}}$ & $4.70 \pm 0.13$ & $13.13 \pm 2.90^{\mathrm{ac}}$ & $70.02 \pm 6.93$ & $9.40 \pm 0.89$ \\
$\mathrm{P}_{3}$ & $4.26 \pm 0.14$ & $1.75 \pm 0.02^{\mathrm{c}}$ & $4.21 \pm 0.07$ & $13.96 \pm 2.65^{\mathrm{ac}}$ & $68.82 \pm 5.68$ & $9.66 \pm 2.64$ \\
\hline Average & $4.02 \pm 0.08$ & $1.48 \pm 0.01$ & $4.00 \pm 0.42$ & $13.66 \pm 3.48^{*}$ & $68.89 \pm 5.42$ & $9.11 \pm 1.58$ \\
\hline
\end{tabular}

$\mathrm{P}_{0}=$ drinking water without probiotic, $\mathrm{P}_{1}=$ drinking water + probiotic $A, \mathrm{P}_{2}=$ drinking water + probiotic $B$ dan $\mathrm{P}_{3}=$ drinking water + probiotic $C$., abc Different superscripts within column with sign ${ }^{* *}$ indicate a highly significant difference $(P<0.01)$, abc Different superscripts within column with sign * indicate a highly significant difference $(P<0.05)$. 
The surface area of the intestine to absorb nutrients is wider in chickens supplemented with probiotics Bacillus sp. than the nonsupplemented (Sjofjan, 2003). Probiotics can change the movement of mucin and microbial populations in the small intestine of chickens in order to improve the intestinal function and health, the composition of microflora in the cecum, and the absorption of food substances (Mountsouris et al., 2010).

The weight of heart and digestive tracts of quail in probiotic treatment were havier than those in control group. It showed that microbial activity in probiotics can provide a higher response to the weight of heart and the digestive tract than other variables. All probiotics contain lactic acid forming bacteria (Lactobacillus) and yeast (Saccharomyces cerevisiae). Lactic acid-forming bacteria such as Lactobacillus can produce acids that reduce $\mathrm{pH}$, thus creating an atmosphere that could prevent pathogenic bacteria from developing (Hatmanti, 2000). Otherwise, the absorption of nutrients is optimal and and the weight of heart $(P<0.01)$ and digestive tract $(P<0.05)$ are significantly higher. Saccharomyces cerevisiae can also oxidize pyruvate to D-lactic acid (Pronk et al., 1996). Carcass weight, liver weight, gizzard weight, digestive tract length and caeca length were not different with or without the liquid probiotic through drinking water.

\section{CONCLUSION}

Liquid probiotics supplementation in quails' drinking water resulted in different final body weight, parameters of digestive and reproduction tracts compared to control group. The supplementation also increased the weight and length of the reproductive tracts. Probiotics A produced the highest final weight, postslaughter weight, dressed carcass weight, liver weight and digestive tracts weight compared to other probiotics.

\section{ACKNOWLADGEMENT}

The authors thank to Dr. Sri Rahayu, M.Si. and Ir. Winarto Hadi, S.U. for providing the probiotic products for this research.

\section{REFERENCES}

Aditiwati, P. and Kusnadi. 2003. Mixed Culture and Environmental Factors of Microorganisms that Play a role in "Tea-Cider" Fermentation. PROC. ITB. Sains \& Tek. 35 A, (2) : 147-162

Altine, S. , M. N. Sabo, N. Muhammad, A. Abubakar, and L. A. Saulawa. 2016. Basic nutrient requirements of the domestic quails under tropical conditions: A review. World Scient if ic News 49(2): 223-235.

Antoine, J. M. 2010. Probiotics in the defence and metabolic balance of the organism Probiotics: beneficial factors of the defence system. The 3rd International Immunonutrition Workshop. Proceedings of the Nutr. Soc. 69: 429-433.

Department of Animal Husbandry and Animal Health of Central Java Province. 2014. Central Java Province animal husbandry statistics in 2014. Ungaran.

Estrada-Cortés, E., H. R. Vera-Avila, J. UrrutiaMorales, E. Villagómez-Amezcua, H. JiménezSeveriano, C. A. Mejía-Guadarrama, M. T. RiveraLozano, and H. G. Gámez-Vázquez. 2009. Nutritional status influences reproductive seasonality in Creole goats: 1 . Ovarian activity during seasonal reproductive transitions. Anim. Reprod. Sci. 116: 282-290.

Hatmanti A., 2000. Pengenalan Bacillus spp. Oseana. 25 (1): 31-41. (Abstract in English)

Hidayat S. C. M., S. Harimurti, and L. M. Yusiati. 2016. Effects supplementation of lactic acid bacteria probiotic on intestinal histomorphology and performance of male quail. Buletin Peternakan Vol. 40 (2): 101-106.

Hilkias, W., E. Suprijatna, Y. S. Ondho. 2017. Pengaruh penggunaan tepung limbah udang fermentasi terhadap karakteristik organ reproduksi pada puyuh petelur (Coturnix coturnix japonica). Jurnal Ilmu-Ilmu Peternakan 27 (2): 8 18.

Kompiang, I. P. 2002. Effect of yeast: Saccharomyces cerevisiae and sea yeast as Probiotic Feed Supplement on the performance of poultry. JITV 7 (1): 18-21.

Kubale, V., K. Merry, G. Miller, M. R. Diaz, and C. S. Rutland. 2018. Avian Cardiovascular Disease Characteristics, Causes and Genomics In: Application of Genetics and Genomics in Poultry 
Science. The University of Nottingham, School of Veterinary Medicine and Science. Catrin Rutland.

Marsudi dan C. Saparinto. 2012. Puyuh. Penebar Swadaya. Jakarta.

Mountzouris, K. C., Tsitrsikos, Palamidi, Arvaniti, Mohnl, Schatzmayr, and K. Fegeros. 2010. Effect of Probiotik Inclusion Levels In Broiler Nurition on Growth Performance, Nutrent Digestiblity, Plasma Imnoglobulin and Cecal Microflora Composition. Poultry science 89(1):58-67.

Prawitya, A. S., M. H. Natsi, and O. Sofyan. 2014. Pengaruh penambahan probiotik Lactobacillus sp. bentuk tepung dalam pakan terhadap kualitas telur ayam petelur. Jurnal Peternakan 13 (3):1-8. (Abstract in English)

Pittman, R. N. and S. Rafael. 2011. The Circulatory System and Oxygen Transpot. In: Regulation of Tissue Oxygenation. Morgan and Claypool LifeScience. Virginia Commonwealth University, Richmond, Virginia

Pronk, J. T., H. Y. Steensmays and J. P. Van Dijken. 1996. Pyruvate Metabolism in Saccharomyces cerevisiae. YEAST 12: 1607-1633.

Resnawati, H. and I. A. K. Bintan. 2014. Need for Native Chicken Feed in A Period of Growth. National Workshop on Local Chicken Development Technology Innovation. Bogor Institut Pertanian Bogor.

Rinawidiastuti, L. Fadhiliya, and T. Ngatman. 2019. Produktivitas Burung Puyuh (Coturnix coturnix japonica) Pengaruh Subtitusi Sari Jahe Gajah
(Zingiber officinale Rosc) Pada Air Minum. Surya Agritama 8 (1): 1-11. (Abstract in English)

Risnajati, D. 2011. Pengaruh Pengaturan Waktu Pemberian Air Minum yang Berbeda Temperatur terhadap Performa Ayam Petelur Periode Grower. Sains Peternakan: Jurnal Penelitian IImu Peternakan, 9(2), 77-81. (Abstract in English)

Sarjana T. A., D. S. Prayitno, L. D. Mahfudz, and I. Irawan. 2010. Female japanese quail spent layer carcass production. IV National Local Poultry Seminar, 7 October 2010. Faculty of Animal Husbandry, University of Diponegoro.

Sjofjan, O. 2003. Probiotic Study (Aspergillus niger and Bacillus sp.) as Ration Additives and Their Implications for Intestinal Microflora and Production Performance of Laying Hens. Disertasi. Universitas Padjadjaran. Bandung.

Sudrajat, D., D. Kardaya, and Sahroji. 2015. Egg Yield of Layer Quail Feed Water Containing Daun Sirih. Jurnal Peternakan Nusantara. 1 (2): 97-104.

Tugiyanti, E., I. H. Sulistyawan, and T. S. Utami. 2018. Bobot Akhir dan Persentase Karkas Puyuh Jantan yang dalam Pakannya Ditambahkan Ampas Teh Fermentasi. Prosiding Seminar Teknologi dan Agribisnis Peternakan VI: 145-147. (Abstract in English)

Widyastuti, W., S. M. Mardiati, and T. R. Saraswati. 2014. Growth of Quail (Coturnix coturnix japonica) after Administration of Turmeric Flour (Curcuma longa L.) in Feed. Buletin Anatomi dan Fisiologi. 22(2):12-20. 